The International Journal of Engineering and Science (IJES)

|| Volume || 6 || Issue || 6 || Pages || PP 16-23 || 2017 ||

ISSN (e): $2319-1813$ ISSN (p): $2319-1805$

THE IJES

\title{
The Effect of Organizational Culture on Organizational Performance: Mediating Role of Knowledge Management and Strategic Planning
}

\author{
Sukanto Toding ${ }^{1}$, Samdin $^{2}$, Rahmat Madjid ${ }^{3}$, Nasrun $^{4}$ \\ ${ }^{1}$ Doctoral Program of Management Science, Halu Oleo University Kendari \\ Southeast Sulawesi, Indonesia \\ ${ }^{2,3,4}$ Faculty of Economics and Business. Halu Oleo University, Southeast Sulawesi, Indonesia
}

\begin{abstract}
The purpose of this study was to determine and analysis the effect of Organizational Cultural on Organizational Performance mediating by Knowledge Management and Strategic Planning. Samples were taken used purposive sampling taking officials of each Head of Department, and Echelon III and IV in Local Revenue Offices Kendari were 42 respondents. Method of data analysis in this study used Partial Least Square (PLS). The results of this study showed that $f$ Organizational Cultural has positive and significant effect on Organizational Performance. Organizational Cultural has positive and significant effect on Knowledge management. Organizational Cultural has positive and significant effect on Strategic planning. Knowledge management has role mediating effect of organizational culture on organizational performance. Strategic planning has role mediating effect of organizational culture on organizational performance. Strategic planning has role mediating effect of knowledge management on organizational performance.

Keywords: Organizational Cultural, Knowledge Management, Organizational Performance, Strategic Planning.
\end{abstract}

Date of Submission: 12 February 2017

$\longrightarrow$

Date of Accepted: 05 June 2017

\section{INTRODUCTION}

Changes in national policies referred carries great hopes for the region to develop their regions to explore the potential of their respective regions as a source of local revenue, especially revenue. Hopes of the area is a natural thing, because it provides a variety of governmental affairs as domestic affairs coupled with a cargo of authority to manage its finances autonomously in finance decentralized governance, both in tapping financial resources, utilization and accountability.

The focus of attention with regard to the financing of regional autonomy rests on the issue of local revenue from various types of sources. That is, revenue is a reflection of the ability of the region in implementing regional autonomy. Article 285 of Law No. 23 Year 2014 on Regional Government which states, "Local revenue sources consist of:

a. Regional Income includes:

1) Local taxes;

2) Levies;

3) The results of separated areas of wealth management; and

4) Miscellaneous revenue (PAD) system;

b. Transfer revenue; and

c. other legitimate income areas. "

If you browse the provisions of Article 285 of the above, it can be seen that among the local revenue sources, only "regional revenue" which is a source of financing as an indication or firmness autonomous local revenue sources. For local revenue sources in the form of equalization funds are the proceeds of which are based certain percentage determined by the balance of the central government. Revenue legitimate area is determined by the size of the jurisdiction set by the Central Government.

Challenges in the reception area in the future, is the tendency of decreasing proportion of the allocation of the Balance Centre, As demands on the establishment of new autonomous regions (DOB), which would also require a new equalization fund (DAU / DAK / Village Fund). Besides, as it is known that since the leadership of President Jokowi (starting in 2015) allocates equalization funds allocated for village (Law No. 06/2014).

Meanwhile, in addition to the inherent challenges redusif revenues Local Government (City Government), on one hand the City Government has significant challenges with revenue generating opportunities in line with 
the dynamics of economic growth in urban areas. But to implement the necessary data and information support systems, knowledge management, innovation, support to the implementation of the legal aspects of strategic management.

Furthermore, among the components of the original income fairly progressive growth, so it needs to be examined is the management component of local taxes and levies which have implications on the juridical aspects of its role in contributing to the local revenue (PAD). In order to optimize taxes and levies, the Government provides broad authority to local governments to explore, expand and intensify the potential of these taxes and fees, as set forth in article 286 of Law No. 23/2014 which reads "local taxes and levies are set by Act whose implementation in the region is further stipulated by the Regional Regulation"

For collection of local taxes and levies implemented in Kendari city government, primarily as a source of revenue. In the face of these challenges, the leaders need to improve their capabilities in deciding the direction of development of the organization which carries out the collection of taxes and levies in this case the Regional Revenue Office Kendari is always more adaptive and innovative in order to survive the environmental conditions continue to fluctuate. Moreover as an organization that has duties as collector PAD then Regional Revenue Office Kendari need to have the strategic flexibility to respond to problems quickly. One effort is the fundamental internal reforming appropriately and healthy, professionally managed organization through proper strategic planning, so as to become a growing department with high mobility, in line with the demands of the development environment. Formulation of strategic planning with systematic academic methods and cara--way right into a vital necessity, because it is through strategic planning, organization / company has the capacity to anticipate the conditions that are always changing (Taylor, 1997; Jauch and Glueck, 2004). Strategic planning provides a road map of activities, the intended direction of the organization and how to achieve it (Shapiro, 2009). Strategic planning can also help leaders of organizations become more strategic leader in running the organization in a rapidly changing environment and uncertain as today (Bryson, 2001). The companies involved in the strategic planning tends more thrive amid severe competition compared to those without (Athiyaman \& Robertson, 1995). Strategic planning is a management tool essential to help the organization do a better job (Alison \& Kaye, 2005), to facilitate strategy development and implementation, as well as the organization becomes more sensitive to customer and market (Bonn \& Christodoulou, 1996; Screwdriver \& Ugboro 2008), Strategic planning (strategic planning) becomes vital needs of the organization, to be successful in maintaining their livelihoods (Robbins \& Coulter, 2007; Hunger \& Wheleen, 2004). Baldrige National Quality Program (2008), setting out strategic planning as one component of superior performance management system.

Strategic planning is an important management tool, which can help in managing in organizations such as the Department of Revenue to be more effective. In addition, the strategic planning is also recognized as absolutely necessary, a strategic planning guidance, direction and basis for moving towards the desired performance in accordance with the vision and mission. However, strategic planning is still a problem due to various constraints faced to be arranged properly and appropriately. The fundamental constraint is related to human resources (HR) and issue data / information necessary to make strategic plans (strategic plan) was good. Strategic planning is important as a management tool for improving the performance and competitiveness of the organization, however, study evaluating the effect of strategic planning on the performance and competitiveness they showed mixed results. There is empirical evidence that strategic planning significantly affect the performance of the organization (Phillips, 1996; Brews \& Purohit, 2007), however, Tanabe et al. (2004) asserts that, it is impossible to run an effective planning, because of the complexity of the organization generate longterm condition that cannot be predicted, making it impossible to implement a strategy that is able to change the competitive position. Other studies have also proved that there is no direct relationship between strategic planning and organizational performance (Zulfadil, 2006; Andersen, 2000; Rudd et al., 2008).

Andersen (2000), Zulfadil (2006) and Rudd et al. (2008), was expanding its research studies to examine the factors that mediate the effect of strategic planning on performance. Andersen proves autonomous actions mediates the relationship of strategic planning and organizational performance, while Zulfadil prove intrapreneurship mediate the association implementation of strategic management and corporate performance, and Rudd et al. proved his versatility mediating influence strategic planning and corporate performance. The research findings Andersen, Zulfadil, and Rudd et al., Also was questioned and less clearly revealed how exactly the mediating variables interact with strategic planning in affecting performance. Limitations of these studies, as well as examine the phenomenon of emerging organizations, an opportunity and motivation to examine further by examining the antecedents of the effectiveness of strategic planning and further affects organizational performance. Brenes et al. (2008) proved that the application of the key success factors of strategic planning is a systematic process of strategy formulation, execution or implementation of an effective strategy, and control and follow-up of implementation.

The flow of information and communication is critical to the overall integration and effectiveness of strategic planning (Ocasio \& Joseph, 2008). In connection with the strategic planning and HR functions, the success of the strategic planning process is highly dependent on the level of the HR department involved. Each 
component of the strategic planning process, namely the formulation, implementation and evaluation of strategies, will involve business issues related -with the prang (people-related business issues), therefore, important HR division is involved in each of these components (Noe et al., 2006 ). Based on theory, previous research and the phenomenon it is an effort to optimize the PAD showed that the performance of the organization at revenue of Kendari still require strategic efforts with and knowledge management and organizational culture can shape efforts strategic planning further build performance improvement organization, so that the findings of this study will also have practical and theoretical implications.

\section{Organizational Culture}

\section{LITERATURE REVIEW}

Culture idea must be learned and shared in the organizations (Titiev, 1959). Pettigrew (1979), argue that cultures of organization based on cognitive systems which help to explain how employees think and make decision. He also noted the different level of culture based on the multifaceted set of beliefs, values and assumptions that determine ways to organizations to conduct its business. According to Tichy (1982), organizational culture is known as "normative glue" means to hold the overall organization together. The concept of organizational culture also makes available a base for determination the differentiation that may survive in-between the organizations that are doing business in the same national culture (Schein, 1990). The concept of culture is generally used in the concept of organizations now-a-days (Kotter and Heskett, 1992). Organizational culture could be build up by two essentials factors of social group; structural stability of a group and integration of single item in superior standard (Schein, 1995). Hodgetts and Luthans (2003), define the different characteristics that are associated with the culture of organization. Culture may defined as system of common values which can be estimated that people describe the similar organization culture even with different background at different levels within the organization (Robbins \& Sanghi, 2007).

\section{Organizational Performance}

Performance refers to the degree of achievement of the mission at work place that builds up an employee job (Cascio, 2006). Different researchers have different thoughts about performance. Mostly researcher's used the term performance to express the range of measurements of transactional efficiency and input \& output efficiency (Stannack, 1996). According to Barney (1991) performance is a continuous process to controversial issue between organizational researchers. Organizational performance does not only mean to define problem but it also for solution of problem (Hefferman and Flood 2000). Daft (2000), said that organizational performance is the organization's capability to accomplish its goals effectively and efficiently using resources. As similar to Daft (2000), Richardo (2001) said that achieving organizational goals and objectives is known as organizational performance. Richardo (2001) suggested that organizations success shows high return on equity and this become possible due to establishment of good employees performance management system.

\section{Knowledge Management}

Knowledge management as a tool being able to gather and arrange available knowledge and spread it in an organization has been important. Accordingly, organizations had to create environment to share, transmit and confront it among members and teach them conceptualization of interact. Investigation, changing and creating an appropriate and flexible organizational culture could only change interactive pattern among employees and knowledge management has been used as competitive advantage (Karami, Gholami, Qanbari, \& Sahafi, 2014).Haney believed (2003) that knowledge management has been scientific field strengthening and encouraging the method of using mutual support to create, possess, organize and use information. Generally, knowledge management could be defined as set of process controlling the creation, spread and use of knowledge. This definition required the creation of organizing and supportive structures, facilitation of relation among members, use of information technology tools and the explanation of knowledge. Malhotra (2005) knew it as doing correct actions than doing action correctly; in other word, he emphasized effectiveness than efficiency. Skyrme (2003) mentioned that it was systematic and implicit knowledge management related to processes of creating, gathering, spreading and using knowledge, but there were two important issues to use it: sharing knowledge and innovating knowledge. Scientific definition of knowledge has been to surround technological tool with usual process of organizational activities in parts overlapping each other

\section{Stratgic Planning}

Shortell \& Kaluzny (1991) describe the strategic plan as providing the mission, values and assumptions of an institution. The strategic plan is important to create a unified and synergistic organization (Beckham, 1992), as well as to help the organization focus on an appropriate direction for changing the organizational culture (Spenner, 1991). In fact, Beckham refers to the plan as a "...blueprint for allocating scarce resources against an organization's best opportunities in an environment of uncertainty and risk" that should "drive long-range plans, 
annual operating plans, facilities, and budgets (p. 68)." In view of the complexities of the healthcare environment, Liedtka (1992) cautions against strategic planning focused solely on a market mentality.

\section{METHOD}

The populations in this study were all civil servants, whose main focus is service to the general public in the collection of taxes and levies on all three offices mentioned above Local Revenue Offices. The sample of this research is using purposive sampling taking officials of each Head of Department, and Echelon III and IV were 42 respondents. This study is a survey so that data collection tool used was research instrument validity and reliability of test results showed that the product moment correlation coefficient for the entire instrument above 0.3 and probability (sig.) Produced less than 0.05 . Furthermore cronbach generated alpha value greater than 0.6 , thus the overall instrument in this study are valid and reliable. Inferential analysis technique used to test the empirical model and the hypothesis proposed in this study.

The analysis technique used is a structural equation model (Structural Equation Modeling - SEM) based variance or Component based SEM, the famous so-called Partial Least Square (PLS). PLS is a factor indeterminacy powerful analytical method, and therefore does not assume the data must be with a certain scale of measurement, the sample size is small, and can also be used to confirm the theory (Ghozali, 2008; Hair et al., 2010.

\section{RESULT}

Hypothesis testing is done by looking at the value of t-test on each track direct effect partially. Results of testing the hypothesis can be seen in table 4.1 and picture 4.1 the following:

Table 4.1. Results Hypothesis testing

\begin{tabular}{|l|l|c|c|c|c|}
\hline \multicolumn{1}{|c|}{$\begin{array}{c}\text { Independent } \\
\text { Variable }\end{array}$} & \multicolumn{1}{|c|}{ Dependent Variable } & $\begin{array}{c}\text { Path } \\
\text { Coeficient }\end{array}$ & t-Count & t-Table & Description \\
\hline Organizational Culture & $\begin{array}{l}\text { Knowledge } \\
\text { Management }\end{array}$ & 0,728703 & 12,997541 & 1,96 & Significant \\
\hline Organizational Culture & Strategic Planning & 0,375953 & 11,945962 & 1,96 & Significant \\
\hline Organizational Culture & $\begin{array}{l}\text { Organizational } \\
\text { Performance }\end{array}$ & 0,139968 & 2,039306 & 1,96 & Significant \\
\hline $\begin{array}{l}\text { Knowledge } \\
\text { Management }\end{array}$ & Strategic Planning & 0,640815 & 21,464859 & 1,96 & Significant \\
\hline $\begin{array}{l}\text { Knowledge } \\
\text { Management }\end{array}$ & $\begin{array}{l}\text { Organizational } \\
\text { Performance }\end{array}$ & 0,265475 & 2,816392 & 1,96 & Significant \\
\hline Strategic Planning & $\begin{array}{l}\text { Organizational } \\
\text { Performance }\end{array}$ & 0,588046 & 4,796709 & 1,96 & Significant \\
\hline
\end{tabular}

Sources: Primary data, (processed) 2016

\begin{tabular}{|c|c|c|c|c|c|c|}
\hline $\begin{array}{c}\text { Independent } \\
\text { Variable }\end{array}$ & $\begin{array}{c}\text { Variabel } \\
\text { Intervening }\end{array}$ & $\begin{array}{c}\text { Dependent } \\
\text { Variable }\end{array}$ & $\begin{array}{c}\text { Indirect Path } \\
\text { Coeficient }\end{array}$ & $\begin{array}{c}\text { Direct Path } \\
\text { Coeficient } \\
\text { Independent } \\
\text { Variable on } \\
\text { Dependent Variable }\end{array}$ & t-Table & Description \\
\hline $\begin{array}{l}\text { Organizational } \\
\text { Culture }\end{array}$ & $\begin{array}{l}\text { Knowledge } \\
\text { Management }\end{array}$ & $\begin{array}{l}\text { Organizational } \\
\text { Performance }\end{array}$ & 0,19345243 & 0,139968 & 1,96 & Contributed \\
\hline $\begin{array}{l}\text { Organizational } \\
\text { Culture }\end{array}$ & Strategic Planning & $\begin{array}{l}\text { Organizational } \\
\text { Performance }\end{array}$ & 0,22107766 & 0,139968 & 1,96 & Contributed \\
\hline $\begin{array}{l}\text { Knowledge } \\
\text { Management }\end{array}$ & Strategic Planning & $\begin{array}{l}\text { Organizational } \\
\text { Performance }\end{array}$ & 0,37682870 & 0,265475 & 1,96 & Contributed \\
\hline
\end{tabular}

Sources: Primary data, (processed) 2016

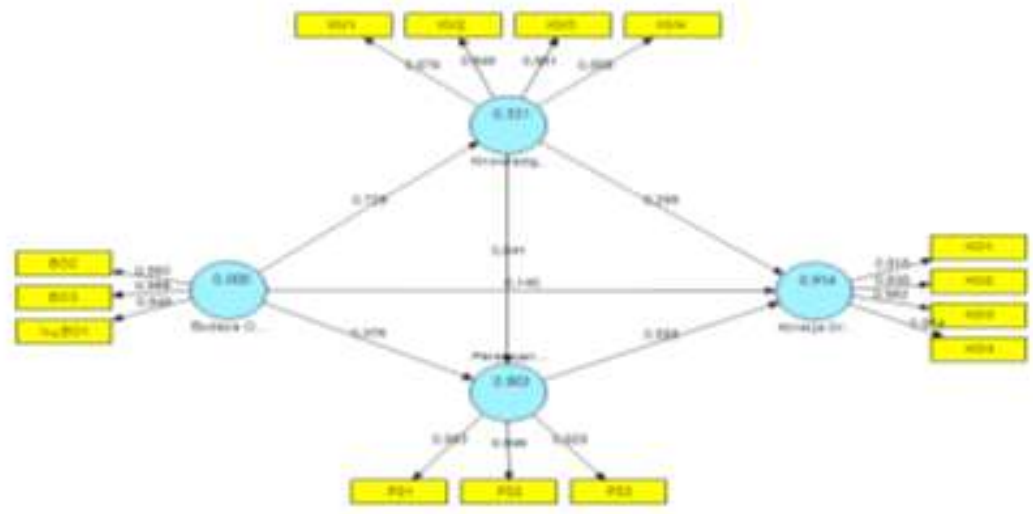


Figure 4.1 The path coefficients between variables

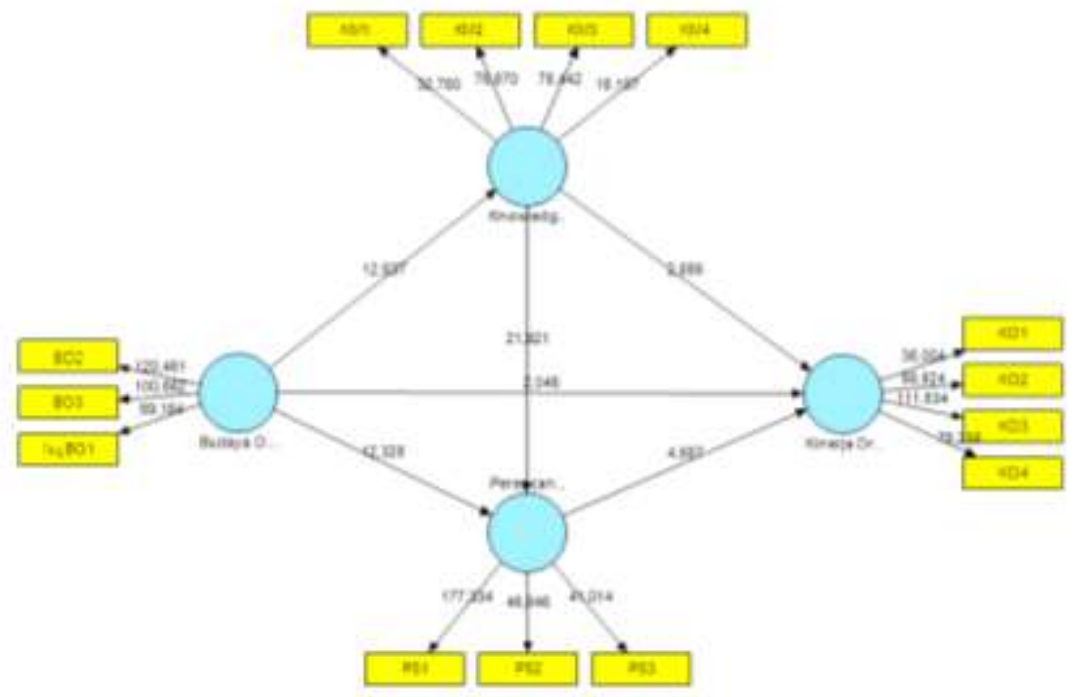

Figure 4.2 The value of $\mathrm{t}$ statistics (t-test) among variables

Based on the table 4.1 and Figure 4.1, further testing hypotheses as follows:

1. The coefficient path to knowledge management organizational culture of 0.728703 with $t$ value of 12.997541. T value is greater than t-table 1.96, so the hypothesis that states the path coefficient significantly influence the organizational culture of knowledge management, accepted.

2. The path coefficients organizational culture to strategic planning at 0.375953 to the $t$ value of 11.945962 . $T$ value is greater than t-table 1.96, thus the hypothesis that organizational culture has significant influence on strategic planning, acceptable.

3. The path coefficients organizational culture to organizational performance by 0.139968 with $t$ value of 2.039306. $\mathrm{T}$ value is greater than $\mathrm{t}$-table 1.96 , thus the hypothesis that organizational culture has significant influence on organizational performance, acceptable.

4. The path coefficients knowledge management into strategic planning at 0.640815 to the $t$ value of 21.464859. $\mathrm{T}$ value is greater than t-table 1.96 , so the hypothesis that states significantly influence knowledge management on strategic planning, acceptable.

5. The path coefficients knowledge management to organizational performance by 0.265475 with $\mathrm{t}$ value of 2.816392. $\mathrm{T}$ value is greater than $\mathrm{t}$-table 1.96 , thus the hypothesis that knowledge management has significant effect on organizationa; performance, accepted.

6. The path coefficients strategic planning to organizational performance by 0.588046 with $t$ value of 4.796709. T value is greater than t-table 1.96, thus the hypothesis of strategic planning significant effect on organizational performance, accepted.

7. The path coefficients of organizational culture on organizational performance through knowledge management by 0.19345243 . These results are greater than the direct path coefficient of organizational culture on organizational performance by 0.139968 . Because the indirect path coefficients of organizational culture on organizational performance through knowledge management is greater than the direct path coefficient of organizational culture on organizational performance, then the hypothesis that knowledge management plays a role mediating influence of organizational culture on organizational performance, acceptable. Furthermore, because the direct path coefficient of organizational culture on organizational performance significantly, the mediating role of knowledge management are included in the category of partial mediation. In other words, in addition to knowledge management, the influence of organizational culture on organizational performance may be mediated by other variables.

8. The path coefficients of organizational culture on organizational performance through the strategic planning of 0.22107766 . These results are greater than the direct path coefficient of organizational culture on organizational performance by 0.139968 . Because the indirect path coefficients of organizational culture on organizational performance through strategic planning is greater than the direct path coefficient of organizational culture on organizational performance, then the hypothesis that a strategic planning role mediating influence of organizational culture on organizational performance, acceptable. Furthermore, because the direct path coefficient of organizational culture on organizational performance significantly, the mediating role of strategic planning included in the category of partial mediation. In other words, in 
addition to strategic planning, the influence of organizational culture on organizational performance may be mediated by other variables.

9. The path coefficients knowledge management to organizational performance through the strategic planning of 0.37682870 . These results are greater than the direct path coefficient knowledge management on organizational performance by 0.265475 . Because the path coefficient indirect knowledge management to organizational performance through strategic planning is greater than the direct path coefficient knowledge management to organizational performance, then the hypothesis that a strategic planning role mediating effect of knowledge management on organizational performance, acceptable. Furthermore, because the direct path coefficient knowledge management to organizational performance significantly, the mediating role of strategic planning included in the category of partial mediation. In other words, in addition to strategic planning, knowledge management influence on organizational performance may be mediated by other variables.

\section{CONCLUSION}

Based on the results of research and discussion in the previous chapter, the conclusions obtained as follows:

1. There is a significant and positive influence between organizational culture to knowledge management. Knowledge management creates a good employee, and then the role of organizational culture in every employee is needed. That is to foster and maintain knowledge management employees, the organizational culture is very important. Organizational culture should be run by each employee so that the implementation of the tasks can be run in accordance with the field which is the specification of an employee.

2. Organizational culture has significant influence on organizational performance. An organizational culture that is getting better, then the performance of Revenue also increased. This means that organizational performance will be achieved if the organizational culture is applied in every employees as needed, so as to nurture and maintain performance, the organizational culture is very important to be applied, it is important for organizational culture as a basis or guidelines in the discharge of an employee to run in accordance with their respective employees.

3. Organizational culture has significant influence on strategic planning. That is, that the cultural organizations are getting better at revenue, has resulted in strategic planning is also getting better. This means that strategic planning produced the better, because the organizational culture applied in every employees as needed, so as to produce a strategic plan to provide direction on the implementation of the organization it is necessary to maintain an organizational culture that exists and is very important to implement, it is important for culture organization as a basis or guidelines in the discharge of an employee that the duties and functions in accordance with the plan of the organization.

4. Knowledge management has significant effect on organizational performance. This means that Knowledge management that is in the employee Local Revenue Offices can improve performance, which means that the better the level of employee knowledge management will further improve the performance. Knowledge management is in acquiring knowledge, sharing or sharing knowledge, storing or documenting knowledge, use or apply knowledge of the opportunities and challenges of the external environment facing and knowledge of internal resources (strengths or weaknesses) owned Local Revenue Offices, either from external sources or internal resources

5. Knowledge management has significant influence strategic planning. This means that an employee who has a good knowledge management at revenue, generate and execute strategic planning too well. This means that the results of this study, it can be said to create a good strategic planning, knowledge management with the ability to both employees. This means that to create or produce strategic planning it is important that a good knowledge management of employee Revenue.

6. There is a significant and positive influence between strategic planning on organizational performance. Organizational performance at revenue showed an increase, this is because of the strategic plan at each Local Revenue Offices also good. That is to nurture and maintain the performance of the organization, strategic planning at every Local Revenue Offices very important. Strategic planning at every Local Revenue Offices should be run so that there are clear guidelines and direction in accordance with the objectives of the organization.

7. Knowledge management has role mediating effect of organizational culture on organizational performance. That is an indirect path coefficients of organizational culture on organizational performance through knowledge management is greater in value than the value of the direct path coefficient of organizational culture on organizational performance. The results of this study illustrate that knowledge management which is owned by employees can contribute and strengthen the influence of organizational culture on organizational performance. 
8. Strategic planning plays a role mediating effect of organizational culture on organizational performance. Research results showed that indirect path coefficients of organizational culture on organizational performance through strategic planning is greater than the direct path coefficient of organizational culture on organizational performance, by doing strategy formulation, strategy implementation and evaluation of strategies on Local Revenue Offices organization.

9. Strategic Planning has role mediating effect between knowledge management and organizational performance. It is based on the findings that the indirect path coefficients knowledge management to organizational performance through strategic planning is greater than the direct path coefficient knowledge management on organizational performance. Besides the importance of the role of strategic planning, for organizations implementing a formal strategic planning is more likely to succeed than those who do not carry out.

\section{SUGGESTION AND LIMITATION}

1. Future studies need to examine more deeply the structural model in this study using a model of reciprocal (reciprocal) which models to test their feed back loop between latent variables, primarily at variable reciprocal knowledge management to strategic planning.

2. In a subsequent study data is used not only cross section of data is data obtained in only one period is only when collecting data through questionnaires so that the data obtained can not be captured more fully but also need to use the data Time Series so that developments in the period of the unit of analysis can be obtained to make it more enriching and more in-depth studies in this research.

3. Collecting data in future studies need to be developed through methods other than using a questionnaire that needs to be added to the interview (interview) is structured to support the results of data collection so that data collection can be used as a tool by the researchers as a good data.

4. The Department of Revenue (Revenue) needs to further improve the existing organizational culture so that it can improve the performance of the organization, supported by the Traffic knowledge management both from employees.

5. Department of Revenue (Revenue) needs to better maintain and improve the quality of strategic planning because it has a strategic role in improving the performance of the organization, but it also needs to increase the organization's culture Local Revenue Offices.

6. Department of Revenue need to develop Human Resources is good quality formal and non-formal primary education in formulating and implementing strategic planning.

7. The Department of Revenue need to develop employee knowledge management capabilities dispense both formal and non-formal primary in formulating organizational strategy in accordance with its duties and functions in Local Government.

A number of findings have been obtained from the results of this study, but there are also limitations in this study can be used as input for further studies in the future. The limitation in this study is that the findings in this study, especially on the outlines Local Revenue Offices performance, taking into account some variables that affect consisting of Culture organization, knowledge management, and strategic planning can not be generalized well in other areas, as well as in other SKPD. This is due to the characteristics of each region is different.

\section{REFERENCES}

[1]Abidi, Syed Sibte Raza. 2001. Knowledge management in healthcare: towards 'knowledge-driven' decision-support services. International Journal of Medical Informatics, 63, 5-18.

[2] Andersen, Torben Juul. 2000. Strategic Planning, Autonomous Actions and Corporate Performance, Long Range Planning, 33, $184-200$.

[3] Athiyaman, A. \& R W Robertson, 1995. Strategic planning in large tourism firms: an empirical analysis. Tourism Management, Vol. 16, No. 3, pp. 199-205.

[4]Bonn, Ingrid \& Chris Christodouiou. 1996. From Strategic Planning. to Strategic. Management.. Long Range Planning, Vol. 29, No. 4, pp. 543 to 551 .

[5]Bornemann, Manfred, Marion Graggo.ber., Erich Hartliieb. Bernd Hump!, Philipp Koronakis, Arthur Primus, Karl Ritsch, Herwig Rollett Martin Sammer Josef Tuppinger Reinhard Willfort \& Kurt WOIs. 2003. An Illustrated Guide to Knowledge Management. Wissensmanagement Forum , Graz, Austria, http://www.wm=forum.orq..

[6]Brenes,. Esteban R, Mau.ricio Mena, German. E. M.ol.ina.. 2008. Key success factors for strategy implementation in Latin America. Journal of Business research, 6, 590-598.

[7] Brews, Peter \& Devavrat Purohit. 2007. Strategic Planning in Unstable Environments. Long Range Planning, 40, $64-83$.

[8]Bryson, John. M. 2001. Strategic Planning for Public and Nonprofit Organizations. M. Miftahuddin (penerjemah). Perencanaan Strategis bagi Organisasi Sosial. Yogyakarta: Pustaka Pelajar Offset.

[9] Ghoneim - Baradei. 2013. The Impact of Strategic Planning on Egyptian Non profits' Performance: An Assessment Using the Balanced Scorecard. Journal of US-China Public Administration, ISSN 1548-6591January 2013, Vol. 10, No. 1, 57-76. Egypt.

[10] Ghozali,. Imam.. 2008, Structural Equation. Modeling Metode Alternatif dengan. Partial Least Square . PLS. Edisi 2.Semarang. Badan Penerbit Universitas Diponogoro.

[11] Hair, Joseph. F. JR, Rolph. E. Andersen. \& .Wiliam. C. Black. 20.1.0. Multivariate. Data. Analysis. e=book 
[12] Harvard. Management Update... 2000.. Corporate Strategy:. A. Manager's Guide. January. http://www.google.com. Download Agustus 2009.

[13] Hitt,. Michael A, R Duane Ireland \& Robert E. Hoskisson. 1997. Strategic management: Competitiveness and Globalization. Armand Hediyanto (penerjemah). Manajemen Strategis: Menyongsong Era Persaingan dan Globalisasi. Jakarta: Erlangga.

[14] Huang, Hao-Chen. 2009. Designing a knowledge-based system for strategic planning: A balanced scorecard perspective. Expert Systems with Applications, 36, 209-218.

[15] Jauch, Lawrence R. \& William F. Glueck. 2004. Strategic Management and Business Policy. 9th Edition. McGraw-Hill Inc.

[16] Lotars - Arturs. 2010. The Role Of Organizational Culture In Human Resource Management. Human Resources Management \& Ergonomics Volume IV.

[17] Noe, Raymond A., John R. Nollenbeck, Barry Gerhart \& Patrick M. Wright. 2006. Human Resource Management, Gaining a Competitive Advantage, 5th Edition. Boston: McGraw-Hill.

[18] Nonaka, Ikujiro. 2006. Creating Sustainable Competitive Advantage through Knowledge-Based Management. htf://www.poogle.com, download, September 2009.

[19] Obeng, Kofi \& Isaiah Ugboro. 2008. Effective strategic planning in public transit systems. Transportation Research Part E 44, 420439.

[20] Ocasio, William \& John Joseph. 2008. Rise and Fall - or Transformation? The Evolution of Strategic Planning at the General Electric Company, 1940 - 2006. Long Range Planning 41, 248- 272.

[21] Phillips, Paul A. 1996. Strategic planning and business performance in the quoted UK hotel sector: results of an exploratory study. Int. J. Hospitality Management Vol. 15 No. 4, pp. 347-362.

[22] Porter, Michael E. 1994. Competitive Advantage. Tim Penerjemah Binarupa Aksara. Keunggulan Bersaing. Jakarta: Binarupa Aksara.

[23] Robbins, Stephen P. \& Mary Coulter. 2007. Management. 8th Ed. Harry Selamet. Manajemen. Jakarta: Indeks.

[24] Rudd, John M., Gordon E. Greenley, Amanda T. Beatson \& Ian N. Lings. 2008. Strategic Planning and Performance: Extending the debate. Journal of Business Research, 61, 99-108.

[25] Sekaran, Uma. 2007. Research Methods For Business, 4th Edition. Kwan Men Yon (Penerjemah). Metodologi Penelitian Untuk Bisnis. Jakarta. Salemba Empat.

[26] Shapiro, Janet, 2009. Strategic Planning Toolkit. http://www.google.com, Download Mei 2009.

[27] Solimun. 2008. Memahami Metode Kuantitatif Mutakhir Structural Equation Modeling dan Partial Least Square. Malang. Program Studi Statistika FMIPA Universitas Brawijaya.

[28] Sugiyono. 2008. Metode Penelitian Bisnis (Pendekatan Kuantitatif, Kualitatif dan R\&D). Bandung, Penerbit Alfabeta.

[29] Tanabe, Mario, Claudio Felisoni De Angelo \& Nicholas Alexander. 2004. The effectiveness of strategic planning: competitiveness in the Brazilian supermarket sector. Journal of Retailing and Consumer Services11,5, 159.

[30] Taylor, Bernard. 1997. The Return of Strategic Planning - Once More with Feeling. Long Range Planning, Vol. \$0, No. 3, pp. 334 to 344.

[31] Zulfadil. 2006. Manajemen strategik, intrapreneurship dan kinerja: Survai pada Koperasi Sekunder KP-Rl. Usahawan no.09.th XXXV, hal. 25-29,September. 